Boston University School of Law

Scholarly Commons at Boston University School of Law

Faculty Scholarship

2004

Politics, Morals and Embryos

George J. Annas

Follow this and additional works at: https://scholarship.law.bu.edu/faculty_scholarship

Part of the Health Law and Policy Commons 


\section{Politics, morals and embryos}

\section{Can bioethics in the United States rise above politics?}

\section{George J. Annas and Sherman Elias}

Bioethics in the United States reflects US culture and tends to be pragmatic, market-oriented and insular. Add embryo politics to this mix and, over the past few years, the result has been a bioethics that has become so narrow and selfabsorbed as to be virtually irrelevant to the rest of the world. Not all the blame for this can be placed on President George W. Bush's political agenda for his President's Council on Bioethics, now in its third year of operation, but much can. The council has made public bioethics the servant of politics by pursuing a narrow, embryo-centric agenda. More remarkably, although the attacks of 11 September 2001 changed almost everything in the US government, the bioethics council - and bioethics in general - were strangely unaffected.

Both the president and the chair of the council, Leon Kass, have cited Aldous Huxley's Brave New World as justification for the council's work. The threats portrayed in this novel - artificial reproduction of humans in state 'hatcheries' and druginduced contentment - are real, but preventing them is not the world's only, or most important, bioethics problem. Both domestic and global access to healthcare, the commercialization of science and medicine, pharmaceutical pricing, conflicts of interest, gene patenting and international research rules merit at least as much attention.

It is understandable, but not acceptable, that a neoconservative bioethics council would have nothing to say about access to healthcare by the tens of millions of uninsured and underinsured Americans. But after 11 September, the president and Congress immediately set about writing new laws that had profound ethical implications for medical research, including the USA Patriot Act, the Bioterror Act and the Bioshield Act. It is almost beyond comprehension that the council had nothing to say about any terrorism-related medical research issues: not about classified biotechnology research; not about the attempted smallpox vaccination of 500,000 US health workers and children; not even about the testing of bioterrorism countermeasures on humans.

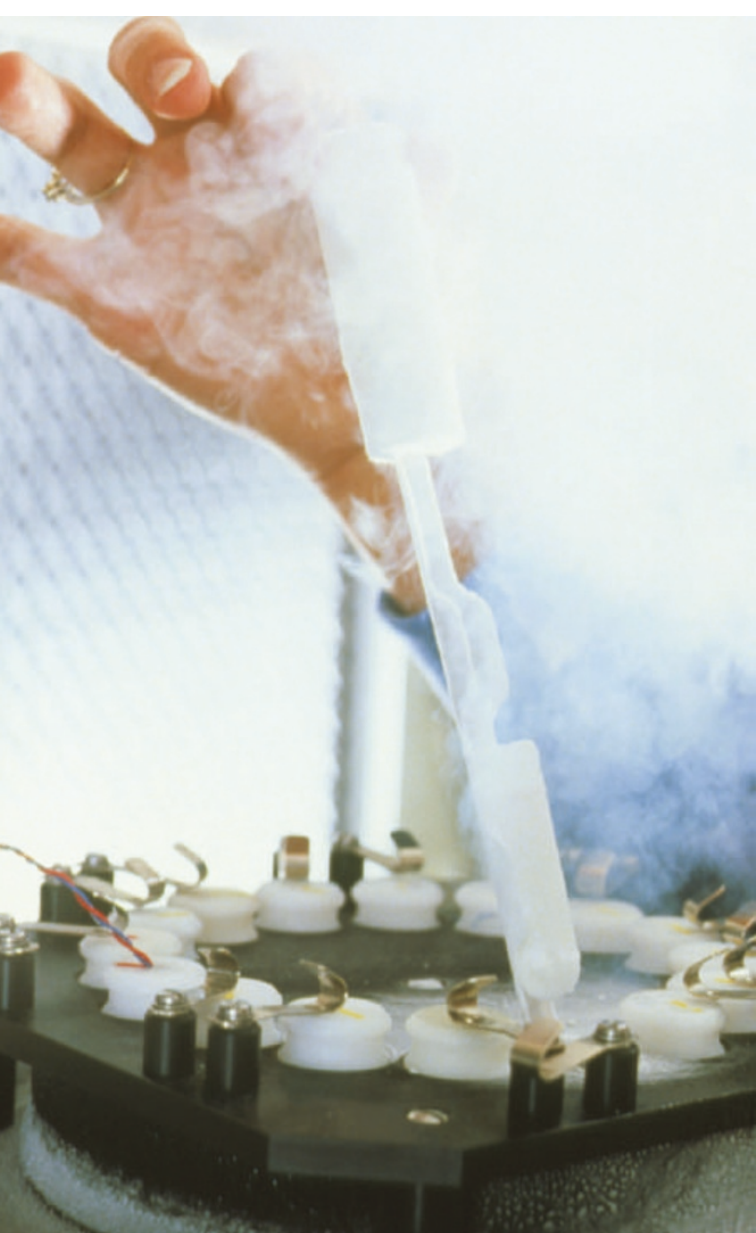

been counterproductive, because embryos do not have the same status as human persons in any humanrights document. But whether it is the failure of US physicians at Abu Ghraib to stop the abuse of Iraqi prisoners there, or the possible ethical shortcuts taken by Korean cloners in obtaining human eggs, a global bioethics based on human rights would demand respect for the human dignity and rights of people - not just embryos. Bioethics in the United States has been noticeably silent on these issues ${ }^{2}$.

Had the United States adopted an international human-rights perspective on bioethics, it too could have joined the UN proposal of August 2001 by France and Germany to draft a treaty to outlaw human reproductive cloning, thereby protecting children. US joint sponsorship of this proposal could have led to the world's first bioethics treaty. Instead, embryocentric bioethics led the United States to effectively kill the proposal by insisting that any cloning treaty simultaneously outlaw the creation of embryos for research purposes.

A full understanding of the President's Council on Bioethics requires recalling its original political agenda. The council was announced by President Bush during a speech on 9 August 2001 in which he said he

Of course, an administration that has declared an open-ended war on terror might not want the bioethics council involved in these discussions. The Bush administration certainly does not want to suggest to US citizens that George Orwell's 1984, with its perpetual war, doublespeak and government reliance on fear, is as relevant to contemporary bioethics as Brave New World. In the war on terror, the nonpartisan US National Research Council has reasonably concluded that controlling biotechnology for terrorism and warfare will require international cooperation ${ }^{1}$. So will meaningful bioethics.

We believe it is the narrow focus of US bioethics, both geographically and philosophically, that permitted terrorism and war to be placed ethically 'off-limits'. The international language of ethics is the language of human rights, and international human rights law in particular, but US bioethics retains an isolationist worldview. From the bioethics council's perspective, using the global language of human rights would have would limit federal funding for embryonic stem-cell research to stem-cell lines that had already been created "where the lifeand-death decision has already been made", and would provide no "taxpayer funding that would sanction or encourage further destruction of human embryos that have at least the potential for life". The council's mandate was to "monitor stem-cell research, to recommend appropriate guidelines and regulations, and to consider all of the medical and ethical ramifications of biomedical innovation".

The bioethics council has so far issued four reports and one collection of readings. Only two of the reports contain policy recommendations. The best known is Human Cloning and Human Dignity (2002), which called on Congress and the president to ban human reproductive cloning and to have a moratorium on research into cloning for therapeutic purposes. The two most recent reports of the commission focus directly on stem cells. Monitoring Stem Cell 
$\overrightarrow{5}$ Research (2003) is a heroic attempt to provide an ethical justification for the stemcell policy articulated in Bush's speech of 9 August 2001. The 'ethics' of the Bush position is based entirely on the argument that taxpayer money should not be spent on destroying any more human embryos in the United States - the private sector and other nations can do what they want. This means that public funding is crucial to the argument.

The council boldly attempts to justify this position, saying: "The decision to fund an activity is... declaration of official national support and endorsement, a positive assertion that the activity in question is deemed by the nation as a whole, through its government, to be good and worthy. When something is done with public funding, it is done, so to speak, in the name of the country, with its blessing and encouragement." This is powerful rhetoric, but wrongly equates politics and morals. It is the criminal law that reflects the nation's minimum morality, not funding decisions ${ }^{3}$. Congress funds, or refuses to fund, thousands of projects that are of interest to only tiny minorities - sometimes called 'special-interest' groups. Federal funding of these projects, whether tobacco-farming subsidies or new nuclear weapon designs, does not imply that they are "deemed by the nation as a whole... to be good and worthy".

State funding decisions are also political. This November, voters in California will decide whether to amend their state constitution to make embryonic stem-cell research for therapeutic purposes a constitutional right, and to provide US $\$ 3$ billion in public funds for stem-cell research. This proposal is excessive, but it is an understandable referendum on the Bush administration's stem-cell policy. It also demonstrates the muddled ethics of the bioethics council, whose overall position would cause it to reject the California initiative, but whose "will of the people" rationale lends support to the idea of voting to determine the morality of this research.

Born with an embryo-centric, antiabortion and anti-regulation political agenda, Bush's President's Council on Bioethics has repeatedly failed to transcend it. In its latest report, Reproduction and Responsibility (2004), the council attempts to come to grips with the ethics of assistedreproduction technology, but ultimately reverts to embryo protection. A thoughtful national report on public oversight for the assisted-reproduction industry is long overdue in the United States. Unfortunately, this report - unlike much earlier UK and Canadian reports - avoids almost all the tough ethical-policy issues in assisted reproduction by concluding that there is insufficient factual information available to make regulatory recommendations.

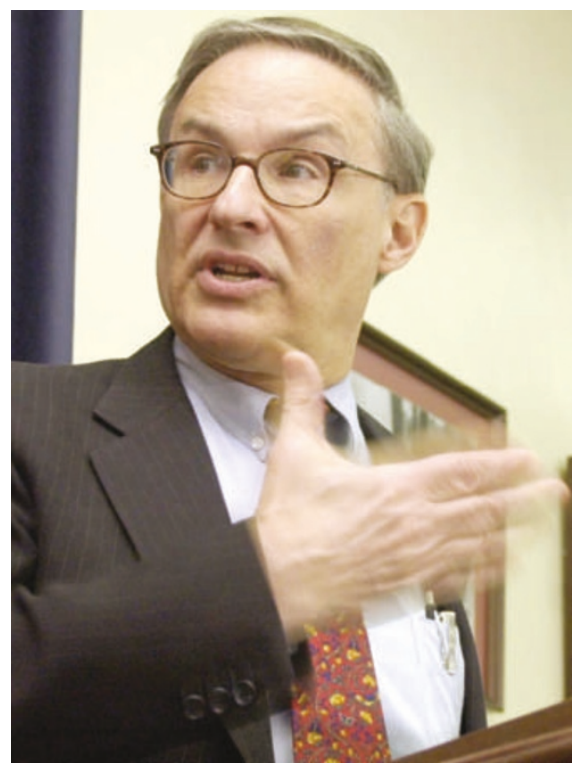

Leon Kass (above) and George Bush have "made public bioethics the servant of politics".

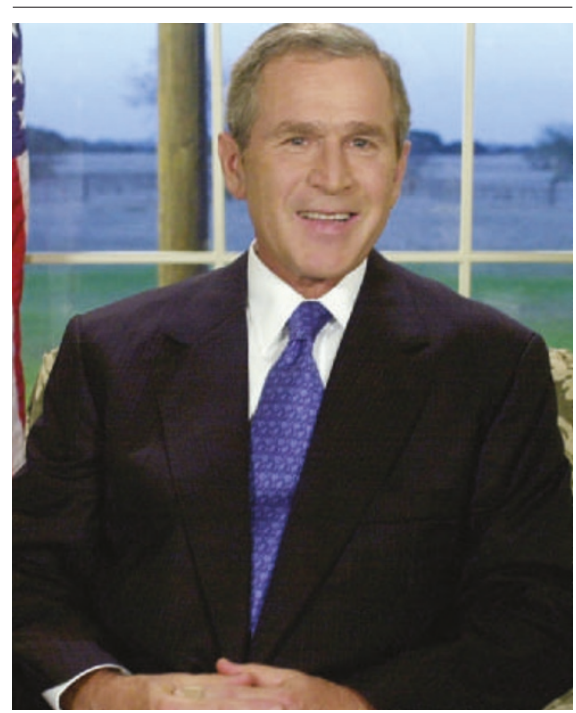

In Reproduction and Responsibility (2004), the council also makes the only legislative recommendations it has made since its cloning report, the most important of which are to "prohibit attempts to conceive a child by any means other than the union of egg and sperm; prohibit the use of human embryos in research beyond a designated stage in their development (between 10 and 14 days after fertilization); and prohibit the buying and selling of human embryos". These prohibitions are reasonable, but a more ethically and politically constructive approach would be for Congress to provide both federal funding and meaningful federal regulatory oversight for embryonic stem-cell research.

During the Clinton administration, we supported the US National Institute of Health's position that federal funding should be available for embryonic stem-cell research conducted with 'surplus' in vitro fertilization embryos donated by couples. However, we noted at the time that the rationale for this limitation on the federal funding of embryo research was political - not ethical ${ }^{4}$ (the moral status of a human embryo no more depends on how or why it was created than does the moral status of a child). It is easier for a politician to support research with 'surplus' embryos than with embryos created for that purpose. But if one believes that embryos should never be created or destroyed for research, such activities should be made a crime, not turned over to an unregulated private sector.

The 'surplus embryo' compromise may still be politically possible, having gained the support of 58 US senators (including some who oppose abortion) and former first lady Nancy Reagan, but not until after the November presidential elections. Given the inability of Bush's bioethics council to provide a credible ethical rationale for his August 2001 position, Bush may pay a political price in the November elections, especially from patient advocates and their families.

Bioethics is important in US politics, just as morality is important in law-making, but when bioethics is used primarily to serve an ideological, domestic political agenda, rather than helping to develop a global ethic, it is of little use to anyone but narrowinterest groups. It is too late to reform Bush's bioethics council. Even mainstream bioethicists who accept the reality that federal panels can never be totally divorced from politics find the politics of this council extreme and isolated ${ }^{5}$. In our view, future bioethics panels in the United States must be independent, not 'presidential'. For the benefit of medicine, science and society, it would be better to establish a permanent National Institute of Bioethics as part of the National Academy of Sciences. Its mandate must be broad, and it should adopt international ethics, especially those embraced in the Universal Declaration of Human Rights, so that it can proceed from a global rather than exclusively US perspective ${ }^{6}$.

George J. Annas is at the Department of Health Law, Bioethics \& Human Rights, Boston University School of Public Health, 715 Albany Street, Boston, Massachusetts 02118, USA.

Sherman Elias is at the Department of Obstetrics and Gynecology, Feinberg School of Medicine, Northwestern University, 333 East Superior Street, Chicago, Illinois 60611, USA.

\footnotetext{
1. Biotechnology Research in an Age of Terrorism (National Academies Press, Washington DC, 2004).

2. Annas, G. J. American Bioethics: Crossing Human Rights and Health Law Boundaries (Oxford Univ. Press, New York, in the press).

3. Fuller, L. The Morality of Law (Yale Univ. Press, New Haven, 1964).

4. Annas, G. J., Caplan, A. \& Elias, S. New Engl. J. Med. 334, 1329-1332 (1996).

5. Charo, R. A. J. Law, Med. \& Ethics 32, 307-314 (2004).

6. The Medical Profession and Human Rights for a Changing Agenda Handbook British Medical Association (Zed Books, London, 2001).
} 